\title{
Difference in tick
}

\section{infestations: Hyalomma \\ dromedariil and Rhipicephalus sanguineus sensu lato in} southern Algeria

\author{
K. Lakehal, R. Saidi, F. Benaceur, M. M. Rahmani, R. Kaidi and \\ N. Mimoune*
}

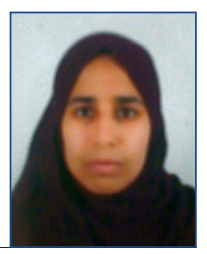

\begin{abstract}
The aim of this study was to identify the species and parasitic indices of ticks. A flock of 57 individuals (sheep, goats, cattle and dogs) in southern Algeria was studied from March 2019 to February 2020 during monthly visits. A total of 2544 ticks were collected by examining the entire body of the animal. Two tick species were identified: Hyalomma dromedarii (2430 ticks) and Rhipicephalus sanguineus sensu lato (114 ticks). The first species had annual activity and
\end{abstract}

consisted only of adults, while the second species had spring and summer activity and contained both adults and nymphs. At the annual level, the prevalence of infestation, abundance, and intensity were $38.60 \%, 44.63$ and 115.64 ticks per animal, respectively. At the monthly level there were speciesspecific fluctuations, with a peak in activity in September.

Key words: Tick, Hyalomma dromedarii, Rhipicephalus sanguineus sensu lato, infestation

Kheira LAKEHAL, MSc, PhD candidate, Department of Biology, Faculty of Sciences, Laboratory of Biological and Agronomic Sciences (LSBA), Telidji Amar University, Laghouat, Algeria; Radhwane SAIDI, PhD, HDR, Senior Lecturer, Associate Professor, Mohammed Mokhtar RAHMANI, DVM, PhD candidate, Assistant Lecturer), Department of Agronomy, Laboratory of Biological and Agronomic Sciences (LSBA), Telidji Amar University, BP 37G, Ghardaïa Road, 03000 Laghouat, Algeria; Farouk BENACEUR, PhD, HDR, Senior Lecturer, Associate Professor, Department of Biology, Faculty of Sciences, Laboratory of Biological and Agronomic Sciences (LSBA), Telidji Amar University, BP 37G, Ghardaïa Road, 03000 Laghouat, Algeria; Rachid KAIDI, PhD, Full Professor, Institute of Veterinary Sciences, Laboratory of biotechnology related to animal breeding, University Saad Dahleb, BP: 270, Soumaa road, Blida, Algeria; Nora MIMOUNE*, PhD, HDR, Senior Lecturer, Associate Professor, (Corresponding author, e-mail: nora.mimoune@gmail.com), Institute of Veterinary Sciences, Laboratory of biotechnology related to animal breeding, University Saad Dahleb, BP: 270, Soumaa road, Blida, Algeria; Higher National Veterinary School of Algiers, Algeria 


\section{Introduction}

Ticks (order: Ixodida) are blood-sucking ectoparasites considered to be among the most important vectors in the phylum Arthropoda (Goddard, 2012). They can transmit a large number of pathogens to domestic and wild animals and even to humans, e.g. bacteria such as Borrelia, Rickettsia, Bartonella, Coxiella, Ehrlichia, Anaplasma (Dantas-Torres et al., 2012), viruses such as meningoencephalitis virus, haemorrhagic fever virus (Moutailler et al., 2016) and parasites such as Babesia and Theileria (Martinot et al., 2011).

These pathogens present a real danger to animals and humans, and are responsible for emerging and/or re-emerging diseases worldwide (De la Fuente et al., 2017), particularly in tropical regions (Jongejan and Uilenberg, 2004). In fact, ticks are considered a major obstacle in improving breeding and they cause significant economic loss (Walker et al., 2003).

In Algeria, few studies have addressed the pathogenic role, biodiversity and dynamics of tick populations (Boulkaboul, 2003). In this sense, such studies are rare in the arid regions of Algeria. Therefore, the aim of the present study was to identify ticks in domestic animals in southern Algeria, in order to better manage and control these pathogens. A second aim was to determine the prevalence, abundance and intensity of annual and monthly tick infestations.

\section{Material and methods}

\section{Study area}

The study was carried out in Sidi Makhlouf in the Laghouat region (southern Algeria, N347'60" $\mathrm{E} 3^{\circ} 1^{\prime} 0^{\prime \prime}$ ), which occupies an area of 142,000 hectares at an altitude of $900 \mathrm{~m}$. It is located about $40 \mathrm{~km}$ north of the city of Laghouat, bounded to the north by the commune of Ain bel, to the east by the commune of Messaad, to the west by the commune of Douais and to the south by the commune of Laghouat (CDF, 2018).

\section{Animals included in the study}

A total of 57 animals were studied during the study period. All the animals were kept in semi-intensive farming systems without acaricide treatment (Table 1).

\section{Collection, conservation and identification of ticks}

Tick collection was carried out monthly over the course of one year; from March 2019 to February 2020. After the animal was restrained, the entire body was examined for ticks, which were gently removed by hand ensuring preservation of the tick body integrity, especially the gnathosoma which plays a very important role in tick species identification (Abdul Hussain et al., 2004). Ticks were then kept in labelled bottles (number, species, sex, date of collection) containing 80\% ethanol, 15\% water, $5 \%$ glycerol and $1 \%$ chloroform (Walker et al., 2003). At the laboratory, ticks were identified using a stereoscopic microscope (ZEISS SteREO Discovery. V8), according to the morphological keys (Estrada-Peña et al., 2017).

\section{Statistical analysis}

The following annual and monthly epidemiological indices were calculated (Bush et al., 1997):

Table 1. Animals included in the study

\begin{tabular}{|l|c|c|c|c|c|}
\hline Animal & Sheep & Goats & Cattle & Dogs & Total \\
\hline Number & 20 & 19 & 14 & 4 & 57 \\
\hline Percentage $(\%)$ & 35.1 & 33.3 & 24.6 & 7.0 & 100 \\
\hline
\end{tabular}


Prevalence: $\mathrm{P}=$ Number of infested animals / Number of animals examined x 100;

Abundance: $\mathrm{A}=$ Number of ticks / Number of animals examined;

Intensity: $\mathrm{I}=$ Number of ticks / Number of infested animals.

\section{Results and discussion}

During the study period, a total of 2544 ticks were collected. The number of collected ticks was variable from month to month. The greatest tick activity was recorded in September, with a percentage of $18.95 \%$, while the lowest was in March $(0.67 \%)$ (Figure 1).

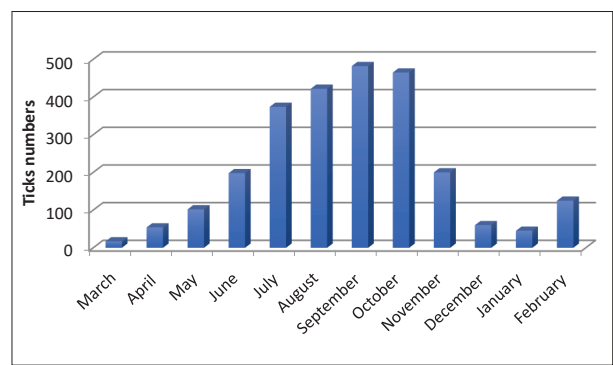

Figure 1. The monthly number of ticks collected (March 2019-February 2020) in the Sidi Makhlouf area

Tick activity was higher in summer and fall, supporting the findings of Benchikh Elfegoun et al. (2013) in northeastern Algeria. The collected ticks included 2490 adults: 1581 males (62.15\%) and 909 females (35.73\%), and 54 nymphs $(2.12 \%)$.

Two species of ticks were collected: Hyalomma dromedarii (2430 ticks or 95.52\%) (Figure 2) and Rhipicephalus sanguineus s.l. (114 ticks or $4.48 \%)$ (Figure 3). The first species was presented throughout the whole year and with a high number while the second species was presented for seven months and with a reduced number (Figure 4).
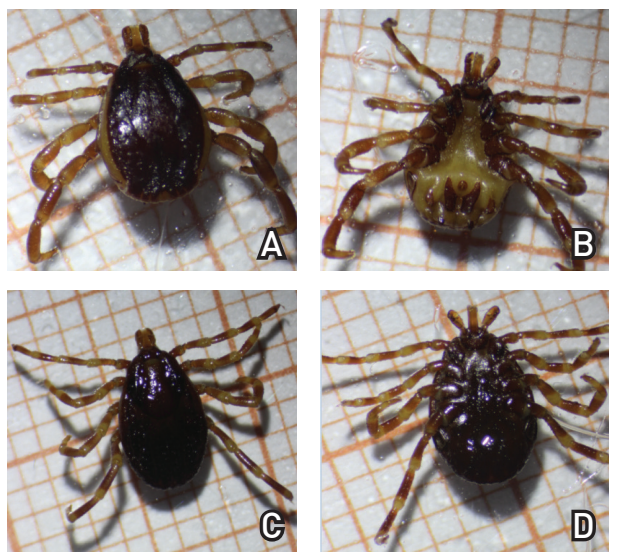

Figure 2. A-D. Hyalomma dromedarii A: Male, dorsal view, B: Male, ventral view, C: Female, dorsal view, D: Female, ventral view.
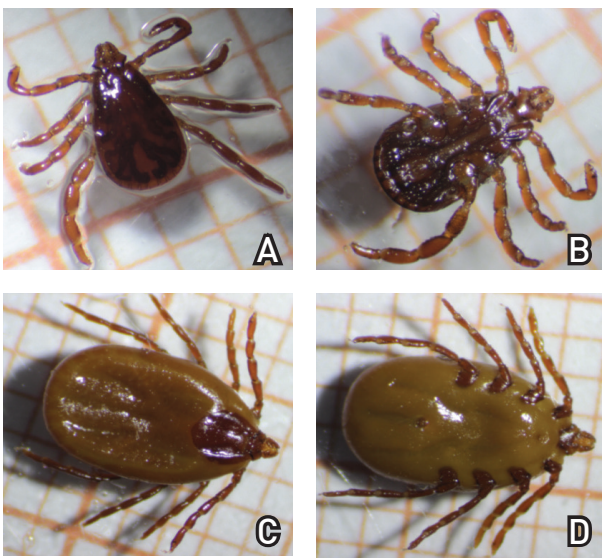

Figure 3. A-D. Rhipicephalus sanguineus s.l. A: Male, dorsal view, B: Male, ventral view, C: Female, dorsal view, D: Female, ventral view

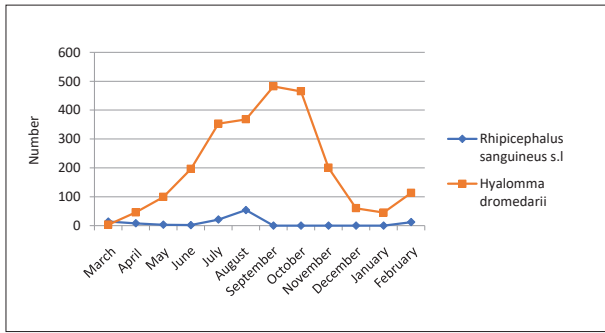

Figure 4. The monthly variation of the number of Hyalomma dromedarii and Rhipicephalus sanguineus s.l. (March 2019-February 2020) in Sidi Makhlouf area 


\section{Epidemiological indices}

During the study period, the annual prevalence of infestation was $38.60 \%$, abundance 44.63 and intensity 115.64 ticks per animal. The data for the monthly level and by animal species are shown in Table 2.

Sheep were only infested in August, when the prevalence, abundance and monthly intensity were $20 \%, 0.75$ and 3.75 ticks per animal respectively. No infestation was observed throughout the study period in goats. This may be due to the immunity of these hosts (Boulkaboul, 2003), or the biotic (climate and environment) and abiotic (age, sex, race and immunity) factors that influence tick infestation prevalence (DantasTorres, 2010; Domșa et al., 2016).

Bouhous et al. (2011) reported the presence of seven species of the genera Hyalomma and Rhipicephalus in Adrar, southwest Algeria. Elati et al. (2018) reported that in Tunisia, sheep were free of any infestations between October and March, while between April and September, the highest prevalence was $19.1 \%$, abundance 0.1 and intensity 1.8 .
Cattle were infested year round, with a prevalence ranging from 7.14 to $100 \%$, abundance between 0.21 and 43.82 and intensity between 3 and 46.50 ticks per animal. Both tick species were collected, with a predominance of Hyalomma dromedarii; a species with annual activity, which is widespread in arid, desert and Saharan bioclimatic zones (Bouattour, 2002). A study carried out by Abdul Hussain et al. (2004) in the Tizi Ouzou region showed the infestation of cattle with 10 species belonging to the genera Boophilus, Rhipicephalus, Hyalomma, Ixodes and Heamaphysalis. Another study by Benchikh Elfegoun et al. (2007) showed infestation with five species belonging to the genera Boophilus, Rhipicephalus and Hyalomma.

Dogs were tick-free between September and January, while both tick species were found on dogs in all remaining months, with a predominance of Rhipicephalus sanguineus sl. The prevalence was between 25 and $100 \%$, abundance between 0.25 and 13.5 and intensity between 1 and 13.5 ticks per animal. In another study (Matallah et al., 2013) found Rhipicepalus sanguineus

Table 2. Distribution of epidemiological indices according to the animal species

\begin{tabular}{|c|c|c|c|c|c|c|c|c|c|c|c|c|c|}
\hline & & Mar & Apr & Mai & Jun & Jul & Aug & Sep & Oct & Nov & Dec & Jan & Feb \\
\hline \multirow{4}{*}{ 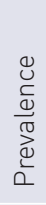 } & Sheep & 0 & 0 & 0 & 0 & 0 & 20 & 0 & 0 & 0 & 0 & 0 & 0 \\
\hline & Goats & 0 & 0 & 0 & 0 & 0 & 0 & 0 & 0 & 0 & 0 & 0 & 0 \\
\hline & Cattle & 7.14 & 50.00 & 71.43 & 78.57 & 78.57 & 78.57 & 100.00 & 90.91 & 72.73 & 55.56 & 77.78 & 77.78 \\
\hline & Dogs & 50 & 75 & 25 & 25 & 100 & 100 & 0 & 0 & 0 & 0 & 0 & 75 \\
\hline \multirow{4}{*}{ 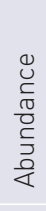 } & Sheep & 0 & 0 & 0 & 0 & 0 & 0.75 & 0 & 0 & 0 & 0 & 0 & 0 \\
\hline & Goats & 0 & 0 & 0 & 0 & 0 & 0 & 0 & 0 & 0 & 0 & 0 & 0 \\
\hline & Cattle & 0.21 & 3.43 & 7.14 & 14.07 & 25.21 & 25.21 & 43.82 & 42.27 & 18.18 & 6.67 & 5.00 & 12.56 \\
\hline & Dogs & 3.5 & 1.5 & 0.5 & 0.25 & 5.25 & 13.5 & 0 & 0 & 0 & 0 & 0 & 3 \\
\hline \multirow{4}{*}{ 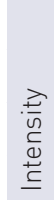 } & Sheep & 0 & 0 & 0 & 0 & 0 & 3.75 & 0 & 0 & 0 & 0 & 0 & 0 \\
\hline & Goats & 0 & 0 & 0 & 0 & 0 & 0 & 0 & 0 & 0 & 0 & 0 & 0 \\
\hline & Cattle & 3 & 6.86 & 10.00 & 17.91 & 32.09 & 32.09 & 43.82 & 46.50 & 25.00 & 12.00 & 6.43 & 16.14 \\
\hline & Dogs & 7 & 2 & 2 & 1 & 5.25 & 13.5 & 0 & 0 & 0 & 0 & 0 & 4 \\
\hline
\end{tabular}


in two bioclimatic regions in the extreme northeast of Algeria, where it was the only species found on dogs of SoukAhras, and represented $77 \%$ of ticks in El-Kala.

\section{Distribution of Hyalomma dromedarii}

The monthly evolution of adult females and males of Hyalomma dromedarii (March 2019-February 2020) in the Sidi Makhlouf area (Figure 5) showed that adult males were more numerous than females $(63.46 \%$ males, $36.54 \%$ females). This difference was due to the behaviour of male ticks. They can mate several times, and stay on the host for longer, while females mate only once and die after oviposition (Sonenshine et al., 1989; Walker et al., 2003; Latif and Walker 2004). The absence of nymphs and larvae is due to their feeding behaviour, i.e. they generally feed on small to medium-sized hosts, while adults feed on larger animals (Stafford, 2007). The hosts of Hyalomma

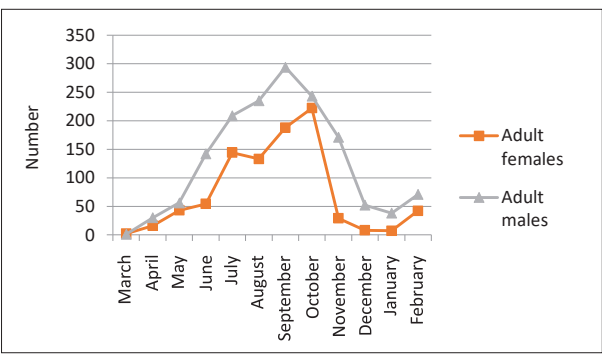

Figure 5. The monthly evolution of adult females and males of Hyalomma dromedarii (March 2019-February 2020) in the Sidi Makhlouf area dromedarii preimagos (nymphs and larves) are mainly rodents, rabbits and birds (Apanaskevich et al., 2008).

In similar studies, this species has been reported on dromedaries in the Adrar region, southern Algeria (Bouhous et al., 2008), and in camels and dogs in Riyadh, Saudi Arabia (Chandra et al., 2019).

In a similar follow-up studies some authors have shown the presence of this species in dromedaries in the Adrar region, southern Algeria, (Bouhous et al., 2008) and in camels and dogs in Riyadh, Saudi Arabia (Chandra et al., 2019).

In the current study, this species was found on cattle and sheep. Figure 6 shows some of the fixation sites in cattle, generally by udders and testicles, sometimes the baleen, the anus margins, the feet, and the belly. Arches and belly were the fixation sites in sheep.

\section{Distribution of Rhipicephalus sanguineus s.l.}

The monthly evolution of nymphs, adult females and males of Rhipicephalus sanguineus s.l. (March 2019-February 2020) in the Sidi Makhlouf area (Figure 7 ) indicated that adults are present for six months, and males are more abundant than females. Nymphs were collected only in August. Rhipicephalus sanguineus can infest domestic and wild animals such as cats, rodents, birds and humans (Walker et al., 2003; Dantas-Torres et al., 2006).
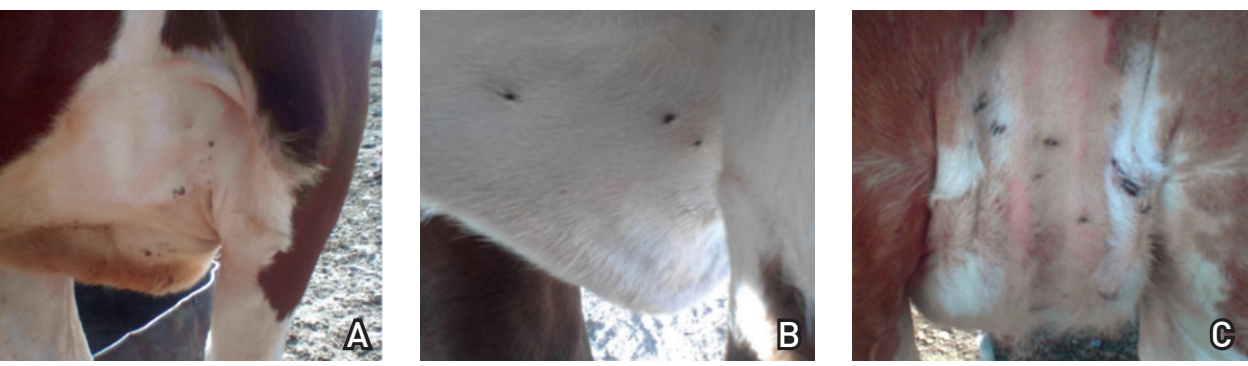

Figure 6. A-C. Hyalomma dromedarii binding sites in cattle 


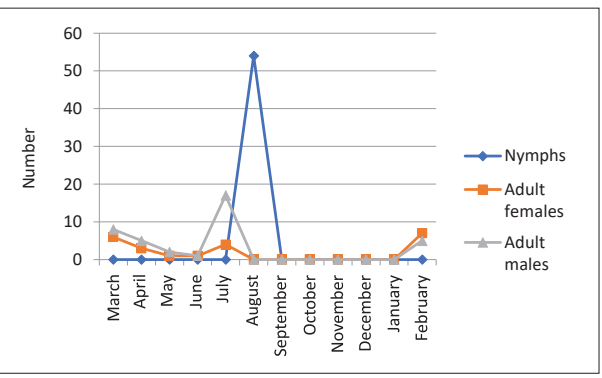

Figure 7. The monthly evolution of Nymphs, adult females and males of Rhipicephalus sanguineus s.l. (March 2019-February 2020) in the Sidi Makhlouf area

Figure 8 shows some of the fixation sites of Rhipicephalus sanguineus s.l. in dogs, generally by the ears, though according to Tinoco-Gracia et al. (2009), this species can attach everywhere on the dog. For cattle, the fixation sites of this species were the same as Hyalomma dromedarii.
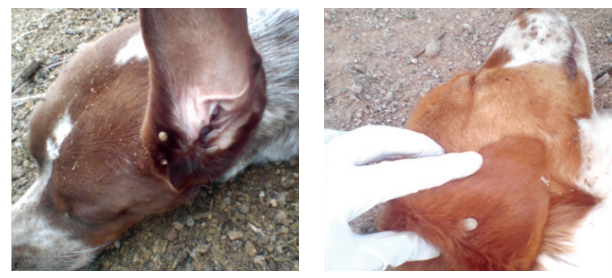

Figure 8. A-B. Rhipicephalus sanguineus s.l. binding sites in dogs

\section{Conclusions}

This study was carried out to determine the different species of ticks found on farm animals in the Sidi Makhlouf area, and to determine the monthly and annual epidemiological indices. The study showed that cattle were the most infested animals, followed by dogs and sheep, while goats were tickfree. During the study period, two tick species were collected and identified: Hyalomma dromedarii $(95.52 \%)$ and Rhipicephalus sanguineus s.l. (4.48\%). The first species had an annual activity while the second had a spring and summer activity.

In view of these results, future surveys should focus on the identification of ticks in different areas and on other animals. In particular, sheep and goats that showed little or no tick infestation in this study.

\section{References}

1. ABDUL HUSSAIN, A. S., I. BITAM, M. S. ABDUL HUSSAIN and V. COZMA (2004): Aperçu sur la dynamique des tiques Ixodidés dans la région de Tizi Ouzou, Algérie. Sci. Parasitol. 1, 175-179.

2. APANASKEVICH, D. A., A. L. SCHUSTER and I. G. HORAK (2008): The genus Hyalomma: VII. Redescription of all parasitic stages of $H$. (Euhyalomma) dromedarii and H. (E.) schulzei (Acari: Ixodidae). J. Med. Entomol. 45, 817-831.

3. BENCHIKH ELFEGOUN, M. C., M. GHARBI, S. DJEBIR and K. KOHIL (2013): Dynamique d'activité saisonnière des tiques ixodidés parasites des bovins dans deux étages bioclimatiques du nord est algérien. Rev. Elev. Med. Vet. Pays Trop. 66, 117-122.

4. BENCHIKH-ELFEGOUN, M., C., A. BENAKHLA, B. BENTOUNSI, A. BOUATTOUR and R. PIARRROUX (2007): Identification de cinétique saisonnière des tiques parasites des bovins ans la région de Taher (Jijel) Algérie. Ann. Med. Vet. 151, 209-214.

5. BOUATTOUR, A. (2002): Clé dichotomique et identification des tiques (ACARI: IXODIDAE). Parasites du bétail au Maghreb. Archs. Inst. Pasteur Tunis. 79, 43-50.

6. BOUHOUS, A., M. AISSI and K. H. HARHOURA (2008): Etude des Ixodidae chez le dromadaire dans le sud algérien, région d'Adrar. Ann. Med. Vet. 152, 52-58.

7. BOUHOUS, A., M. AISSI and K. HARHOURA (2011): Prevalence of Ixodidae in sheep brought for slaughter in Adrar municipal abattoir, Southwest Algeria. Sci. Parasitol. 12, 197-201.

8. BOULKABOUL, A. (2003): Parasitisme des tiques (Ixodidae) des bovins à Tiaret, Algérie. Rev. Elev. Med. Vet. Pays Trop. 56, 157-162.

9. BUSH, A. O., K. D. LAFFERTY, J. M. LOTZ and A. W. SHOSTAK (1997): Parasitology meets ecology on its own terms: Margolis et al. revisited. J. Parasitol. $83,575-583$

10. CDF (2018): Conservation des forêts de la wilaya de Laghouat.

11. CHANDRA, S., K. SMITH, A. D. ALANAZI, M. S. ALYOUSIF, D. EMERYAND and J. ŠLAPETA (2019): Rhipicephalus sanguineus sensu lato from dogs and dromedary camels in Riyadh, Saudi Arabia: low prevalence of vector-borne pathogens in dogs detected using multiplexed tandem PCR panel. Folia Parasitol. 66, 007. doi: 10.14411/ fp. 2019.007

12. DANTAS-TORRES, F. (2010): Biology and ecology of the brown dog tick Rhipicephalus sanguineus. Parasites Vector. 3, 1-11.

13. DANTAS-TORRES, F., B. B. CHOMEL and D. OTRANTO (2012): Ticks and tick-borne diseases: a one health perspective. Trends Parasitol. 28, 437-446. 
14. DANTAS-TORRES, F., L. A. FIGUEREDO and S. P. BRANDAO-FILHO (2006): Rhipicephalus sanguineus (Acari: Ixodidae), the brown dog tick, parasitizing humans in Brazil. Rev. Soc. Bras. Med. Trop. 39, 64-67.

15. DE LA FUENTE, J., S. ANTUNES, S. BONNET et al. (2017): Tick-pathogen interactions and vector competence: identification of molecular drivers for tick-borne diseases. Front. Cell. Infect. Microbiol. 7, 114

16. DOMȘA, C., A. D. SÁNDOR and A. D. MIHALCA (2016): Climate change and species distribution: possible scenarios for thermophilic ticks in Romania. Geospat. Health 11, 421.

17. ELATI, K., D. HAMDIA, M. JDIDIA, M. REKIKB and M. GHARBIA (2018): Differences in tick infestation of Tunisian sheep breeds. Vet. Parasitol. 13, 50-54.

18. ESTRADA-PEÑA, A., A. D. MIHALCA and T. PETENY (2017): Ticks of Europe and North Africa: A Guide to Species Identification. Published by Springer International Publishing, p. 404.

19. GODDARD, J. (2012): Physician's guide to arthropods of medical importance. $6^{\text {th }}$ ed. Boca Raton. London New York. CRC Press. Taylor et Francis Group, p. 535.

20. JONGEJAN, F. and G. UILENBERG (2004): The global importance of ticks. Parasitol. 129, S3-S14.

21. LATIF, A. A. and A. R. WALKER (2004): An introduction to the biology and control of ticks in Africa, p. 29.

22. MARTINOT, M., M. M. ZADEH, Y. HANSMANN,
I. GRAWEY, D. CHRISTMANN, S. AGUILLON, M. JOUGLIN, A. CHAUVIN and D. DE BRIEL (2011): Babesiosis in immunocompetent patients, Europe. Emerg. Infect. Dis. 17, 114-116.

23. MATALLAH, F., A. BENAKHLA and A. BOUATTOUR (2013): Infestation du chien par Rhipicephalus sanguineus dans deux régions de l'extrême nord-est de l'Algérie. Rev. Elev. Med. Vet. Pays Trop. 66, 97-101.

24. MOUTAILLER, S., C. VALIENTE MORO, E. VAUMOURIN et al. (2016): Co-infection of Ticks: The Rule Rather Than the Exception. PLoS Negl Trop Dis. 10, 3.e0004539.

25. STAFFORD, K. C. (2007): Tick Management Handbook. An integrated guide for homeowners, pest control operators, and public health officials for the prevention of tick-associated disease. The Connecticut Agricultural Experimentation Station, p. 84.

26. TINOCO-GRACIA, L., H. QUIROZ-ROMERO, M. T. QUINTERO-MARTINEZ, T. B. RENTERIAEVANGELISTA, Y. GONZALEZ-MEDINA, A. BARRERAS-SERRANO， S. HORI-OSHIMA， M. H. MORO and J. VINASCO (2009): Prevalence of Rhipicephalus sanguineus ticks on dogs in a region on the Mexico-USA border. Vet. Rec. 164, 59-61.

27. WALKER, A. R., A. BOUATTOUR, J. L. CAMICAS, A. ESTRADA-PENAA, I. G. HORAK, A. A. LATIF, R. G. PEGRAM and P. M. PRESTON (2003): Ticks of domestic animals in Africa: a guide to identification of species. Biosci. Rep., Edinburgh Scotland, U.K., p. 227.

\section{Razlika u infestaciji krpeljima: Hyalomma dromedarii i Rhipicephalus sanguineus sensu lato na jugu Alžira}

Kheira LAKEHAL, MSc, PhD candidate, Department of Biology, Faculty of Sciences, Laboratory of Biological and Agronomic Sciences (LSBA), Telidji Amar University, Laghouat, Algeria; Radhwane SAIDI, PhD, HDR, Senior Lecturer, Associate Professor, Mohammed Mokhtar RAHMANI, DVM, PhD candidate, Assistant Lecturer), Department of Agronomy, Laboratory of Biological and Agronomic Sciences (LSBA), Telidji Amar University, BP 37G, Ghardaïa Road, 03000 Laghouat, Algeria; Farouk BENACEUR, PhD, HDR, Senior Lecturer, Associate Professor, Department of Biology, Faculty of Sciences, Laboratory of Biological and Agronomic Sciences (LSBA), Telidji Amar University, BP 37G, Ghardaïa Road, 03000 Laghouat, Algeria; Rachid KAIDI, PhD, Full Professor, Institute of Veterinary Sciences, Laboratory of biotechnology related to animal breeding, University Saad Dahleb, BP: 270, Soumaa road, Blida, Algeria; Nora MIMOUNE, PhD, HDR, Senior Lecturer, Associate Professor, Institute of Veterinary Sciences, Laboratory of biotechnology related to animal breeding, University Saad Dahleb, BP: 270, Soumaa road, Blida, Algeria; Higher National Veterinary School of Algiers, Algeria

Ova je studija provedena na jugu Alžira u svrhu identifikacije vrste i parazitskih indeksa krpelja, a proučavano je stado u vremenskom razdoblju od ožujka 2019. do veljače 2020. uz učestalu posjetu jednom mjesečno. Ispitivanjem cijelog tijela životinje prikupljena su ukupno 2544 krpelja ispitivanjem cijelog tijela životinje. Identificirane su dvije vrste krpelja: Hyalomma dromedarii (2430 krpelja) i Rhipicephalus sanguineus sensu lato (114 krpelja). Prva vrsta bila je aktivna cijelu godinu i sadržavala je samo odrasle jedinke, dok je druga vrsta bila aktivna u proljeće i jesen i sadržala je i odrasle i nimfe. Pojavnost infestacije, brojnost i intenzitet bili su $38,60 \%$, 44,63, odnosno 115,64 krpelja godišnje po životinji. Na mjesečnoj razini te ovisno o vrsti životinje, bilo je fluktuacija, s vrhuncem aktivnosti u rujnu.

Ključne riječi: krpelj, Hyalomma dromedarii, Rhipicephalus sanguineus sensu lato, infestacija 